\title{
Microbiological Examination of Erwinia amylovora Exopolysaccharide Ooze
}

\author{
Suzanne M. Slack, Quan Zeng, Cory A. Outwater, and George W. Sundin
}

All authors: Department of Plant, Soil, and Microbial Sciences, Michigan State University, East Lansing 48824; and second author: Department of Plant Pathology and Ecology, Connecticut Agricultural Experiment Station, New Haven 06504.

Accepted for publication 23 December 2016.

\begin{abstract}
Fire blight, caused by the pathogen Erwinia amylovora, is the most devastating bacterial disease of pome fruit in North America and worldwide. The primary method of dispersal for E. amylovora is through ooze, a mass of exopolysaccharides and bacterial cells that is exuded as droplets from infected host tissue. During the 2013 and 2014 field seasons, 317 ooze droplets were collected from field-inoculated apple trees. Populations of E. amylovora in ooze droplets were $10^{8} \mathrm{CFU} / \mu \mathrm{l}$ on average. Ooze droplets harboring larger $\left(>10^{8} \mathrm{CFU} / \mu \mathrm{l}\right)$ cell populations were typically smaller in total volume and had darker coloring, such as orange, red, or dark red hues. Examination of apple host tissue at the site of emergence of ooze droplets using scanning electron microscopy revealed that ooze was not exuding through natural openings; instead, it was found on erumpent mounds and small $(10-\mu \mathrm{m})$ tears in tissue. These

observations suggested that E. amylovora-induced wounds in tissue provided the exit holes for ooze extrusion from the host. Analyses of E. amylovora populations in ooze droplets and within the stems from which ooze droplets emerged indicated that approximately $9 \%$ of the total bacterial population from infected stems is diverted to ooze. Gene expression analyses indicated that E. amylovora cells in stem sections located above ooze droplets and in ooze droplets were actively expressing critical pathogenicity genes such as $h r p L, d s p E$, and $a m s K$. Thus, our study identified ooze as a source of large, concentrated populations of E. amylovora that emerged from the host by rupturing host tissue. Because the cells in ooze droplets are expressing genes required for pathogenesis, they are already primed for infection should they be dispersed from ooze to new infection courts.
\end{abstract}

Erwinia amylovora (Burrill) Winslow et al., a rod-shaped, gramnegative bacterium that is a member of the Enterobacteriaceae family, is the causal agent of fire blight, the most devastating bacterial disease that occurs in apple and pear. E. amylovora is thought to be native to North America, arising as a pathogen on hawthorn and other native Rosaceae species. The introduction of apple and pear to North America by European settlers in the late 1600s presented new Rosaceae species that were more susceptible to fire blight than the native species, ultimately resulting in the occurrence of epidemic spread of fire blight in these new plantings (van der Zwet and Keil 1979; Vanneste and Eden-Green 2000).

Fire blight is particularly difficult to manage because the pathogen can actively infect all host tissues and at different times of the season. A hallmark of fire blight disease is that very large bacterial populations can develop relatively quickly both externally on flower stigmas and internally within infected leaves at shoot tips and within stems. The pathogen is also capable of rapid systemic movement in young trees, often within one season, from infected shoots downward through trees to the rootstock (Momol et al. 1998). Infection and canker formation that girdles rootstocks then results in tree death (Norelli et al. 2003). Under conducive environmental conditions especially associated with storms with damaging winds and hail, the spread of fire blight can occur extremely rapidly within and between orchards in the early summer when actively growing, susceptible shoot tissue is present.

The spread of fire blight in pome fruit orchards occurs mostly from pathogen cells that emerge from infected host tissue in ooze droplets. Ooze, a mixture of bacterial cells and exopolysaccharides (EPS), is the most important epidemiological component of fire blight (Thomson 2000) and serves as both the primary and a secondary form of inoculum for the transmission of fire blight. The primary inoculum for fire blight in the spring consists of ooze that emerges

Corresponding author: G. W. Sundin; E-mail address: sundin@msu.edu

(c) 2017 The American Phytopathological Society onto the surface of cankers that have overwintered (Schroth et al. 1974; Vanneste and Eden-Green 2000). E. amylovora cells present in ooze from viable cankers are thought to be dispersed via rain, wind, and insects such as flies to the surface of flower stigmas. Once stigmas are colonized by E. amylovora, bacterial populations can grow to as large as $10^{6-7}$ cells/flower within 1 to 2 days if growthconducive temperatures occur (Johnson et al. 2006; Miller and Schroth 1972; Pusey and Curry 2004). The availability of free moisture from rain or heavy dew is required for E. amylovora cells to migrate from the stigma tip down the style to flower nectaries, where the pathogen infects flowers through natural openings, ultimately causing blossom blight (Thomson 1986).

Following blossom blight infection, pathogen cells begin to migrate systemically within the tree but can also emerge from flower pedicel and stem tissues as ooze droplets, providing inoculum for secondary spread of the pathogen to shoot tips. The newly emerging leaf tissue at the tips of actively growing apple shoots is highly susceptible to fire blight infection. The most significant aspect of shoot infection by E. amylovora is that infections can be initiated by very low cell numbers; for example, as few as 35 to 100 cells could cause shoot infections in inoculation experiments (Crosse et al. 1972). Once shoot infection occurs, E. amylovora cells migrate systemically through infected leaf and stem tissue toward the central leader (main trunk) of the tree. During this migration, ooze droplets can also emerge from stem tissue in variable number and location. Ooze emergence is preceded by the development of large internal bacterial populations within stems (Gowda and Goodman 1970). This ooze continues to serve as inoculum for secondary cycles of infection of new shoots, which can occur throughout the summer until shoots set their terminal bud and growth ceases.

Ooze droplets produced by E. amylovora range in color from white to dark brown and include yellow, orange, red, and other shades of various colors (Fig. 1A to 1D; Hildebrand 1939; van der Zwet et al. 2012). Ooze droplets of different colors can occur adjacent to one another on the same stem or fruit tissue (Fig. 1E), and it is common to observe large numbers of ooze droplets exuding from infected fruit (Fig. 1F). The emergence of ooze droplets from infected tissue can 
occur quite rapidly after infection, typically in just a few days after flower or shoot infection (Fig. 1G). It has been hypothesized that colors of ooze that are not white or dark brown were contaminated with other organisms (Hildebrand 1939); however, this hypothesis has not been supported experimentally. In addition to ooze, E. amylovora cells can emerge from host tissue in aerial strands, which can be colorless, amber, or brick red from apple (Eden-Green and Billing 1972); however, the occurrence of aerial strands is quite rare. E. amylovora ooze consists of bacterial cells and the EPS amylovoran (Bennett and Billing 1979; Eden-Green and Knee 1974; Sijam et al. 1983). Amylovoran is a pathogenicity factor for E. amylovora, because amylovoran-deficient mutants are incapable of causing disease symptoms (Bernhard et al. 1993). Amylovoran is also a key component of the E. amylovora biofilm, which is an important virulence factor required for colonization of xylem tissue in infected leaves (Koczan et al. 2009). In addition, amylovoran has been hypothesized to function in the masking of E. amylovora cells from host recognition and resistance responses (Geider et al. 2006). Thus, the presence of amylovoran in ooze is important because some level of amylovoran association with cells would be necessary to ensure successful infection following dissemination to new host tissue.

The method of escape of ooze droplets from host tissue has been widely debated in the phytopathology literature for decades (Billing 1981; Hildebrand 1939; Seemüller and Beer 1976; Schouten 1991; Zamski et al. 2007). There does not seem to be a consensus on whether ooze droplets passively seep from the plant via natural openings or burst out from the parenchyma cell layer. Because E. amylovora does not produce cell-wall-degrading enzymes, the bacterial cells may be directly causing wounds and breaking through plant cell layers. This could be due to pressure of the expanding EPS through water absorption and accompanying swelling (Seemüller and Beer 1976; Schouten 1989b). The "pressure hypothesis" was also substantiated by Zamski et al. (2007), who used transmission electron microscopy studies of inoculated pear stems to observe large osmiophyllic droplets, which they interpreted as ooze droplets, in intercellular spaces of bark parenchyma tissue. These authors also stated that ooze exuded through lenticels on stems but did not provide any microscopic evidence (Zamski et al. 2007).

We have maintained a long-term interest in the fire blight pathosystem, particularly in examining mechanistic aspects of infection and correlating this with the results of genetic studies of host-pathogen interactions. Although ooze is one of the most conspicuous aspects of fire blight disease, to our knowledge, a comprehensive, microbiological examination of E. amylovora ooze has never been conducted. Our goals in this study were to determine the population size of E. amylovora in ooze droplets, assess the allocation of $E$. amylovora cells from internal stem populations to ooze, examine the mechanism of egress of E. amylovora from stems, and comparatively examine the expression of critical virulence determinants from both internal stem sections and ooze droplets.

\section{MATERIALS AND METHODS}

Examination of ooze droplets from field-inoculated apple shoots. E. amylovora strain Ea110, a spontaneous rifampicinresistant mutant from Michigan (Zhao et al. 2005), was manually inoculated to apple trees in an orchard located on the Michigan State University (MSU) Plant Pathology farm in East Lansing. The host trees, Malus $\times$ domestica 'Kit Jonathan,' were grafted onto M9 rootstock. The inoculum was prepared using cell suspensions grown in Luria-Bertani (LB) broth at $28^{\circ} \mathrm{C}$ for $12 \mathrm{~h}$. Prior to inoculation, populations were adjusted using a Tecan Safire spectrometer (Männedorf, Switzerland) to $1 \times 10^{6} \mathrm{CFU} \mathrm{ml}^{-1}$ in $0.5 \times$ phosphatebuffered saline (PBS). These cell suspensions were maintained on ice until inoculation, occurring less than $1 \mathrm{~h}$ after the suspension was prepared. The inoculation method used involved horizontally cutting the youngest unfolded leaf of an actively growing shoot across the midvein using sterile scissors dipped into the cell suspension. This process removed approximately one-fourth to one-third of the tip of the leaf (McGhee and Sundin 2011).

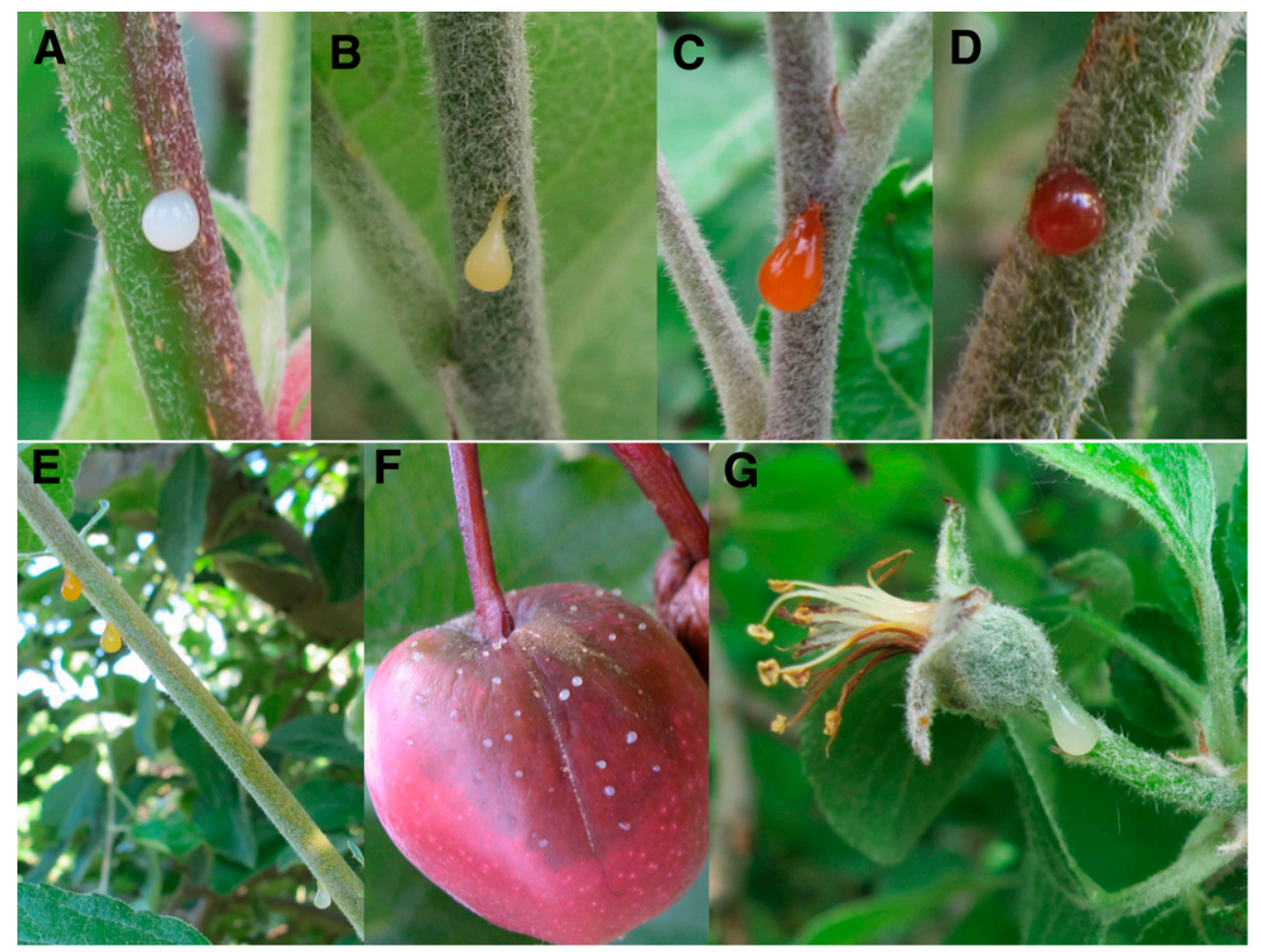

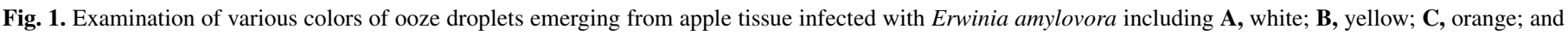

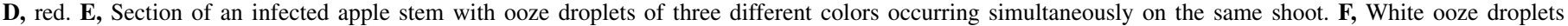

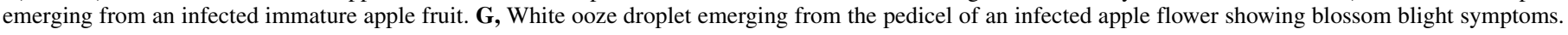


Inoculations occurred weekly throughout the growing season, starting in late May and ending in early July, resulting in seven inoculations in both 2013 and 2014.

When present in the early morning, bacterial ooze droplets were collected from infected shoots using sterile 0.6-ml microcentrifuge tubes by scraping the ooze droplet off the branch using the inner lip of the lid cylinder of the tube. This scraping method ensured that the entire ooze droplet was collected into the tube. Only ooze deemed fresh, not hardened, and less than $24 \mathrm{~h}$ old, was collected. For each ooze droplet, the color, physical location on the stem, date, current weather conditions, and shoot number were documented. In 2014, the distance from the ooze droplet to the previous year's bud scar was also documented. Collected ooze droplets were brought to the laboratory on ice, $100 \mu \mathrm{l}$ of $0.5 \times$ PBS buffer was added to the sample tube, and the mixture was vortexed until the ooze droplet was completely dissolved in buffer. Next, $100 \mu \mathrm{l}$ of the solution was removed from the 0.6-ml tube and added to a $1.5-\mathrm{ml}$ microcentrifuge tube containing $900 \mu \mathrm{l}$ of $0.5 \times$ PBS to be further diluted. The remaining solution in the original $0.6-\mathrm{ml}$ tube was removed using a $10-\mu \mathrm{l}$ micropipettor to take consecutive $1-\mu \mathrm{l}$ samples until all the liquid was removed, which was determined to be the original volume of the ooze droplet. The $100 \mu \mathrm{l}$ of the original solution was then serially diluted, and appropriate dilutions were drop plated onto LB medium amended with rifampicin at $100 \mu \mathrm{g} \mathrm{ml}^{-1}$ to select for strain Ea1 10 and with cycloheximide at $50 \mu \mathrm{g} \mathrm{ml}^{-1}$ to inhibit fungal growth $(\mathrm{LBrc})$. The colony counts were used to determine the original population of E. amylovora in the ooze droplet.

Determination of internal population sizes of $E$. amylovora from inoculated apple stems. From some samples, in addition to collecting the ooze droplet, a 3-cm section of the stem tissue containing the exuded ooze droplet and adjacent $1-\mathrm{cm}$ stem sections above and below the ooze droplet were collected and assayed to determine internal E. amylovora populations. Each stem piece was cut into three sections, based on the location of the exuded ooze droplet. The middle section, termed section $\mathrm{B}$, consisted of $0.5 \mathrm{~cm}$ on either side of the ooze drop, resulting in a 1-cm section. The top section, termed section $\mathrm{A}$, was the $1-\mathrm{cm}$ piece above section $\mathrm{B}$ and the bottom, termed section C, was directly under section B (Fig. 2). Each stem section was weighed and then finely diced using a sterile razor blade. The diced pieces were placed into sterile glass tubes containing $9 \mathrm{ml}$ of $0.5 \times$ PBS buffer. The solution was then homogenized using a PT 10-35 polytron (Brinkmann, Westbury, NY) for 3 to $5 \mathrm{~s}$ (McGhee and Sundin 2011). The homogenate was serially diluted, and appropriate dilutions were plated onto LBrc medium. This experiment was conducted twice in a growth chamber using E. amylovora Ea110 on 'Buckeye Gala' apple on EMLA 7 rootstock and repeated in the field in 2014 using Ea110 on Kit Jonathan apple. The two growth chamber experiments were exact replicates and showed no significant differences when statistically analyzed using the methods indicated in the statistical methods section of this article; thus, the results from both experiments were pooled together.

Scanning electron microscopy. All scanning electron microscopy (SEM) samples were processed in the Center for Advanced Microscopy at MSU with the JEOL 7500F (JEOL, Tokyo) and Olympus Soft Imaging Solutions (Olympus, Münster, Germany). Samples were fixed in paraformaldehyde/glutaraldehyde (2.5\% of each compound in $0.1 \mathrm{M}$ sodium cacodylate buffer) (Electron Microscopy Sciences, Hatfield, PA). The tissue was dehydrated with ethanol, then critical point dried (Balzers CPD, Balzers, Lichtenstein). Tissue was sliced after critical point drying to reduce potential artifacts from the fixation process and then mounted on aluminum mounting stubs using carbon tabs (Electron Microscopy Sciences).

Analysis of virulence gene expression of $E$. amylovora in apple stem tissue and ooze. E. amylovora Ea110 was cultured in LB and inoculated on apple shoots in the field using the previously described dipping scissors method. In total, 17 ooze droplets were collected from individual apple shoots from four different field- grown apple cultivars: 'Linda McIntosh', $n=5$; Kit Jonathan, $n=5$; 'Gala', $n=3$; and 'September Wonder Fuji', $n=4$. Ooze droplets were collected 4 to 6 days after inoculation on five sampling dates in 2013. Early-stage infected shoots from Linda McIntosh and Kit Jonathan trees were collected at $48 \mathrm{~h}$ postinoculation on 14 June, and section A stem samples from Linda McIntosh and Kit Jonathan trees were collected from shoots $1 \mathrm{~cm}$ above the ooze droplets on the same sampling date as the ooze droplets. For in vitro gene expression analyses, E. amylovora Ea110 was first cultured in LB and then incubated in Hrp-inducing minimal medium (Hrp MM) (Guttman et al. 2002) for $12 \mathrm{~h}$. In total, three separate samples were analyzed for early-stage infected shoots and section A samples from each cultivar. Three samples each from LB and Hrp MM were analyzed for in vitro gene expression. Three technical replicates were included for each sample collected.

Total RNA was isolated from cells from the LB culture and the Hrp MM culture as negative and positive controls for type III secretion system (T3SS) gene expression. Total RNA was isolated on the same sampling dates using an E.Z.N.A. Plant RNA Kit (Omega Biotek, Norcross, GA) and an miRNeasy kit (Qiagen, Valencia, CA). The quality and quantity of RNA isolated was examined using a Nanodrop1000 (Thermo Scientific, Waltham, MA) and a bioanalyzer (Agilent Technologies, Santa Clara, CA). Reverse transcription was performed using TaqMan reverse transcription reagents (Applied Biosystems, Waltham, MA). Quantitative reverse-transcription polymerase chain reaction (qRT-PCR) was performed by a StepOnePlus Real-Time PCR System (Life Technologies, Carlsbad, CA), using a SYBR Green PCR master mix (Applied Biosystems). The PCR amplification specificity was confirmed using a melting curve method. The housekeeping gene $\operatorname{rec} A$ was used as an endogenous control. The expression of target genes was quantified by a comparative cycle threshold (CT) method $(\Delta \Delta \mathrm{CT})$, normalized by the endogenous control. Gene expression levels in ooze droplets and plant samples were presented as the fold expression in comparison with the expression observed in Ea1 10 grown in LB culture. Primers used for qRT-PCR were recA (F:5'-ATCATTGTTGACTCCGTTGC, R: 5'-CATTGCCTGGCTCATCATAC), $h r p L$ (F:5' - GATCTGGAG CAAATGACCTG, R: 5' - TTTAAGGCAATGCCAAACAC), $d s p E$ (F: 5'-CGCAACATCGGAACCATTAA, R: 5'-TGCGACCTGCG GATTAGC), and amsK (F: 5'-CGGCACGCTGAAATCATTC, R: 5'-TGCCGCAAAGGGCTTTT).

Statistical analysis. Statistical analysis was preformed using JMP Pro (version 12.0.1; SAS Institute Inc., Cary, NC). E. amylovora

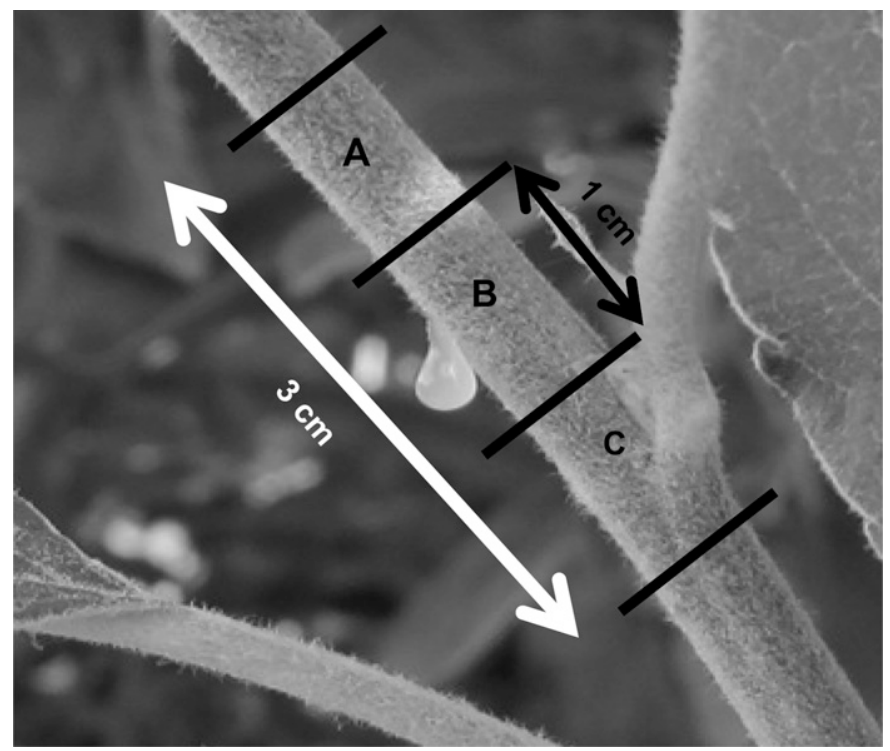

Fig. 2. Diagram of sections A, B, and C of apple stems used in sampling for internal populations of Erwinia amylovora surrounding an ooze droplet. 
population values were $\log _{10}$ transformed prior to analysis. A one-way analysis of variance was performed for each experiment separated by year. Means within studies were compared using Tukey's honestly significance difference test.

\section{RESULTS}

Evaluation of ooze droplets by color, volume, and pathogen population. In total, 317 ooze droplets were collected in 2013 and 2014 from field-inoculated Kit Jonathan apple trees (Table 1). The ooze droplets ranged in color from white to dark red (Fig. 1A to 1E). Orange was the most prevalent color, with 91 and 44 droplets in 2013 and 2014, respectively, accounting for $47 \%$ of the total droplets sampled (Table 1). Yellow droplets were the largest in volume, averaging 4.89 and $6.10 \mu \mathrm{l}$ in 2013 and 2014, respectively (Fig. 3). However, the yellow droplets did not differ significantly in volume from red droplets in 2013 (Fig. 3A) or from dark-red droplets in 2014 (Fig. 3B). The volumes of ooze droplets of other colors varied by year, with smaller volumes in general observed in 2013 compared with 2014 (Fig. 3). Of the various colors of ooze droplets produced by E. amylovora Ea110, significant differences in populations on a permicroliter basis were observed between red and white droplets in both 2013 and 2014 (Fig. 4A and C). Populations in all of the droplets, regardless of color, were very large, greater than or close to $10^{8} \mathrm{CFU} / \mu \mathrm{l}$ in 2013 and greater than $10^{6} \mathrm{CFU} / \mu \mathrm{l}$ in 2014. The most consistent result observed when analyzing $E$. amylovora populations per ooze droplet was that white ooze droplets harbored significantly smaller populations compared with red ooze droplets in both years, with an overall difference of approximately 10-fold (Fig. 4B and D).

Internal populations of $E$. amylovora from apple stems surrounding ooze droplets. Apple stem pieces, approximately $3 \mathrm{~cm}$ in length, surrounding ooze droplets were excised for population analyses. The ooze droplets were carefully scraped off the stem pieces, which were then dissected into three 1-cm sections for population analysis (termed sections A, B, and C) (Fig. 2). In field experiments in 2013 with inoculated shoots of Kit Jonathan, we did not observe significant differences in internal population from any of the three sections. However, the ooze droplet population was significantly lower than the internal populations (Fig. 5A). However, when the same experiment was repeated twice in the growth chamber on Buckeye Gala trees, we observed a significant difference between section $\mathrm{B}$ and the other internal populations as well as the ooze droplets (Fig. 5B). The overall percentage of bacteria within and exuding from section B in the ooze droplet showed that the E. amylovora population in ooze comprised a relatively small percentage of the total bacteria present compared with the internal population; only $9 \%$ was located in ooze whereas section B populations comprised $44 \%$ of the total E. amylovora present in the section of shoots in the field. The ooze droplets collected in the growth chamber experiments were, on average, $14 \%$ of the total population whereas section $\mathrm{B}$ retained $51 \%$ of the population of E. amylovora present in the sample.

SEM analysis of ooze droplet extrusion from apple stems and fruit. In SEM micrographs of collapsed ooze droplets from infected fruit samples, bacterial cells could clearly be observed emerging from wounded tissue (Fig. 6A to C). When we scraped away ooze droplets prior to fixation and observation, exit wounds

TABLE 1. Quantification of ooze droplets by color collected from Kit Jonathan apple trees that were inoculated with Erwinia amylovora Ea110 in 2013 and 2014

\begin{tabular}{|c|c|c|c|c|c|c|}
\hline \multirow{2}{*}{$\begin{array}{l}\text { Year of } \\
\text { collection }\end{array}$} & \multicolumn{5}{|c|}{ Color of ooze droplet } & \multirow{2}{*}{$\begin{array}{c}\text { Total } \\
\text { per year }\end{array}$} \\
\hline & Dark red & Red & Orange & Yellow & White & \\
\hline 2013 & 15 & 39 & 91 & 44 & 22 & 201 \\
\hline 2014 & 9 & 13 & 44 & 22 & 22 & 116 \\
\hline Total & 24 & 52 & 150 & 66 & 44 & 317 \\
\hline
\end{tabular}

were readily visualized as well as EPS (Fig. 6B). We consistently observed wounds that appeared to serve as exit points for ooze droplets in fruit samples (Fig. 6C). We did not observe natural openings near collapsed ooze droplets; any tearing of tissue near ooze droplets appear to be an artifact from the SEM fixation, because tearing was also observed in uninfected fruit of the same cultivar and age (data not shown). Erumpent mounds (large convexshaped mounds with a central tear) were observed underneath large ooze droplets emerging from apple stems (Fig. 6D). These mounds were also visible with the naked eye after ooze droplets were removed. These mounds appear to have been formed from internal pressure based on the shape of the stem or petiole tissue.

Analysis of $E$. amylovora virulence gene expression in apple stem tissue and ooze. We assessed the expression of pathogenicity genes involved in either the T3SS ( $h r p L$ and $d s p E)$ or amylovoran biosynthesis (amsK) in apple shoots located near the inoculation point at shoot tips at $48 \mathrm{~h}$ after inoculation, apple stem sections immediately adjacent to an ooze droplet at 4 to 6 days after

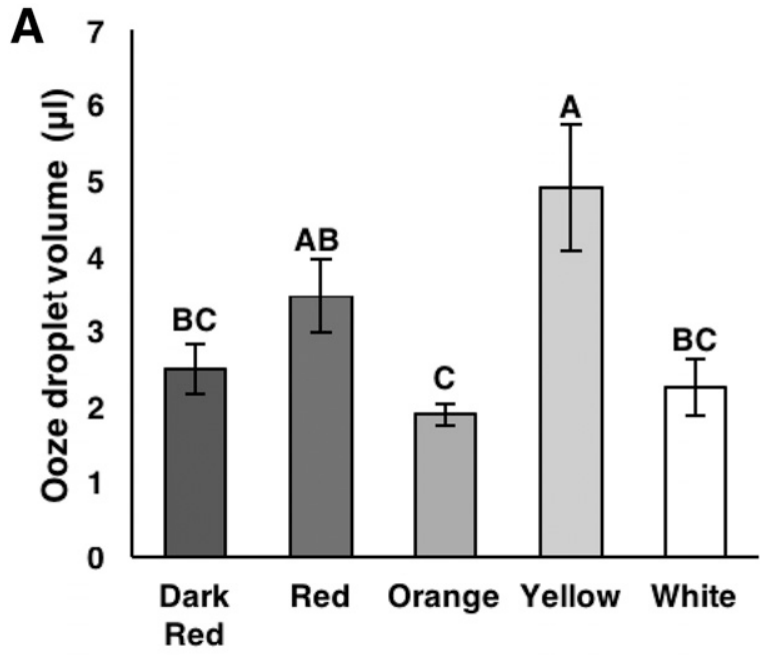

Ooze droplet colors

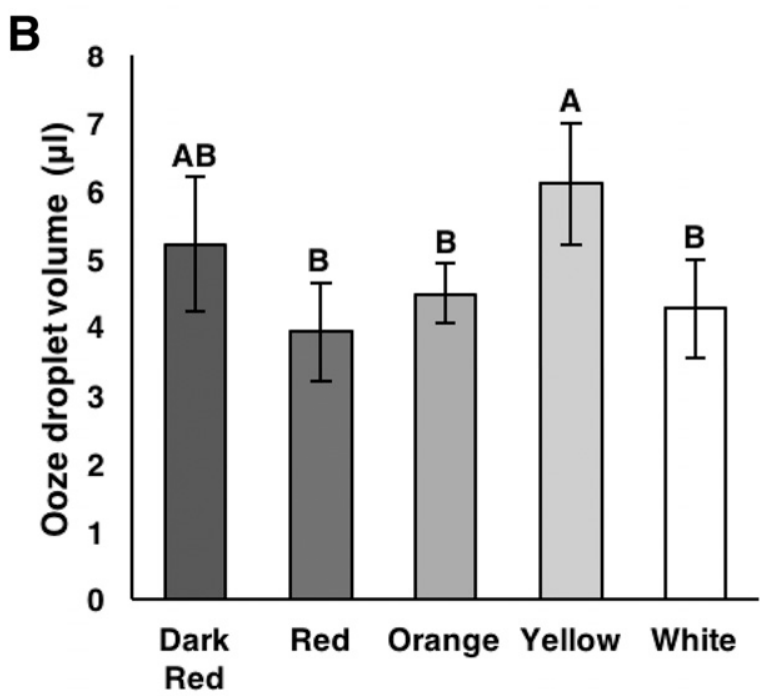

\section{Ooze droplet colors}

Fig. 3. Mean Erwinia amylovora ooze droplet volume (sorted by color) isolated from the field-inoculated Kit Jonathan apple trees inoculated with E. amylovora Ea110. Ooze droplet volumes from A, 2013 (201 droplets) and B, 2014 (116 droplets). Error bars represent standard error of the means, $P<0.05$. Bars with the same letter above them represent values that are not significantly different in the same year based on Tukey's honestly significance difference, $P<0.05$. 
inoculation, and from cells recovered from ooze droplets. $h r p L$ encodes an alternate $\sigma$ factor that is required for the expression of T3SS genes, including the major effector gene $d s p E$ (Oh and Beer 2005; McNally et al. 2012). amsK is located within the ams operon encoding amylovoran biosynthesis. The expression of $h r p L, d s p E$, and $a m s K$ in the collected plant samples was compared with their expression under an in vitro T3SS repressive condition (LB) and an in vitro T3SS induction condition.

hrpL expression was elevated in stem sections from both cultivars compared with the expression level observed in cells incubated in vitro in Hrp MM (Fig. 7A). Although hrpL expression was lower in cells assessed directly from ooze droplets from each cultivar, the expression level was still equivalent to that of cells from $\operatorname{Hrp~MM~(Fig.~7A).~} d s p E$ expression was lower than $h r p L$ expression from cells recovered from the stem sections and the ooze droplets, and approximately 4- to 8-fold lower than the expression level in Hrp MM (Fig. 7B). amsK expression was slightly higher from cells recovered from stem sections than from cells recovered from ooze droplets or from cells grown in Hrp MM (Fig. 7C). Similar results were observed when gene expression was assessed from E. amylovora cells in ooze droplets and stem sections from Gala and September Wonder Fuji trees (data not shown). The most noticeable difference observed in gene expression from the Linda McIntosh and Kit Jonathan cultivars was a distinction in expression of $h r p L$ from the early-stage infection and section A stem samples (Fig. 7A to C).

\section{DISCUSSION}

Our field and laboratory data indicated that E. amylovora populations within ooze droplets were extremely large, populations were consistently higher in darker-colored ooze droplets, and cells present in ooze droplets were expressing genes required for pathogenesis, suggesting that these cells would be primed for infection if disseminated to susceptible host tissue. When considering the average volume of ooze droplets examined and the population size of E. amylovora determined per microliter, overall populations per individual ooze droplet ranged from $10^{6}$ to $10^{10}$ cells. E. amylovora ooze functions in the epidemiology of fire blight through direct dissemination of bacterial cells via rainsplash, wind, or insect activity to new host infection sites (Schroth
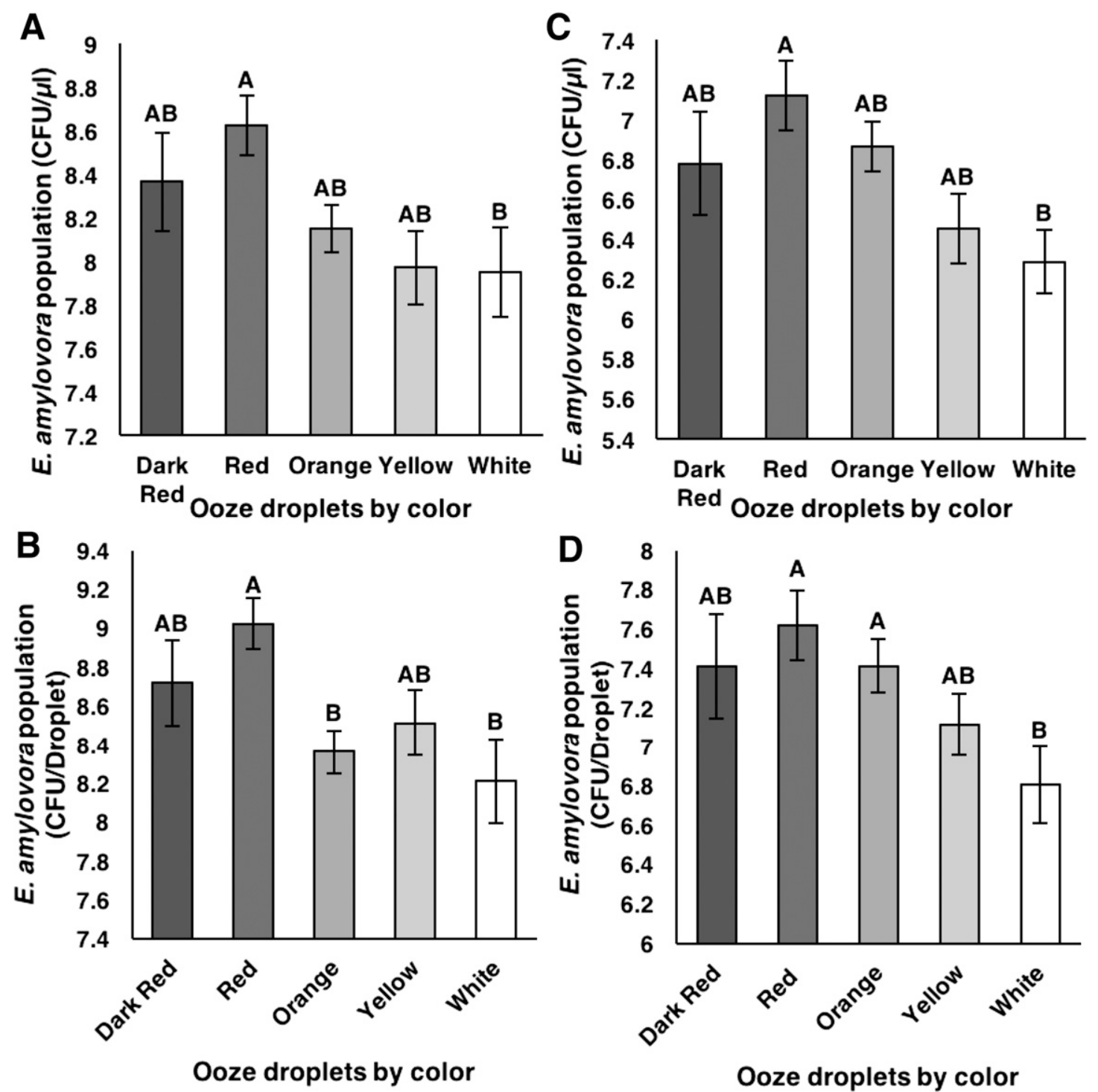

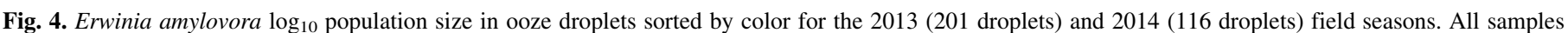

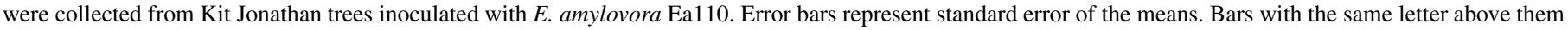

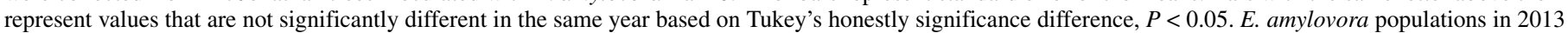

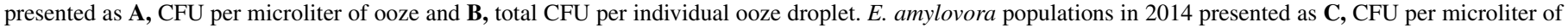
ooze and D, total CFU per individual ooze droplet. 
et al. 1974); a second function is in long-term survival, because E. amylovora cells in dried ooze droplets can remain viable and pathogenic for periods of 1 to 2 years (Hildebrand 1939; van der Zwet and Keil 1979). The E. amylovora populations in ooze are many orders of magnitude larger than those necessary to establish infections in inoculated, wounded apple shoots. For example, Crosse et al. (1972) determined that a median inoculum dose of only 38 bacterial cells was required for shoot infection following pipetting of a droplet of cells onto the cut end of the main leaf veins of an apple leaf at the shoot tip, and Ruz et al. (2008) reported a median effective pathogen dose of $2.01 \times 10^{5}$ cells using the most effective inoculation method of cutting an apple leaf with scissors dipped in cell inoculum.

Why, then, might E. amylovora populations in ooze droplets be so large? In nature, ooze from cankers supplies primary inoculum for flower infection, and E. amylovora cells are primarily disseminated

A

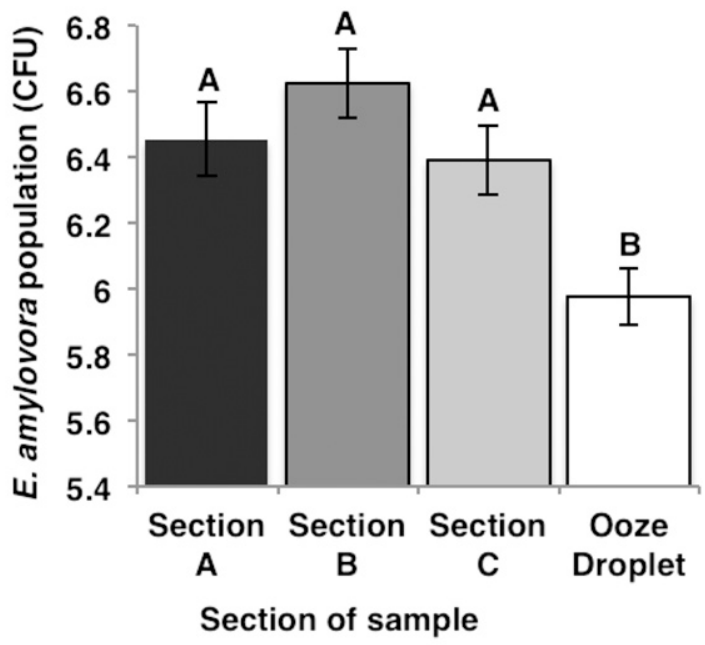

B

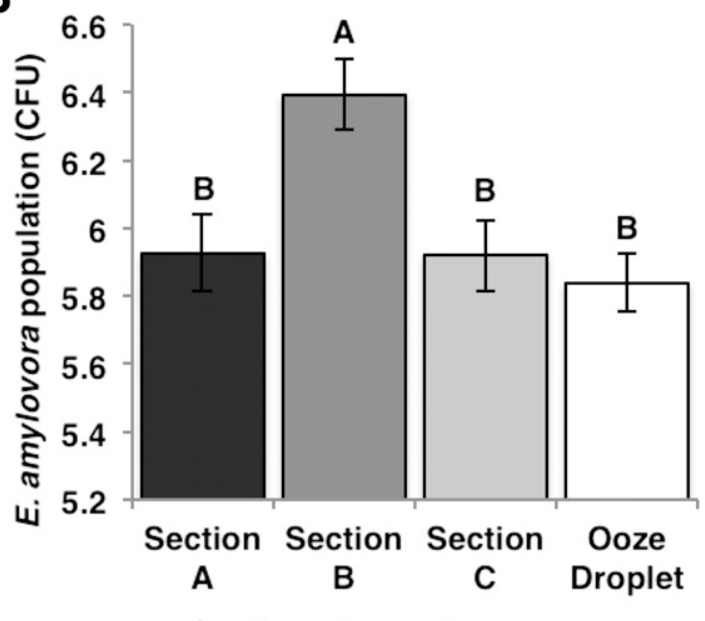

Section of sample

Fig. 5. Erwinia amylovora internal populations sampled from the three stem sections (A, B, and C) and the ooze droplet that had emerged from section B of the stem. Each section was $1 \mathrm{~cm}$ in length, with the ooze droplet in the center $(0.5 \mathrm{~cm})$ of section B. Error bars represent standard error. Bars with the same letter above them represent values that are not significantly different in the same year based on Tukey's honestly significance difference. A, Average size of E. amylovora internal populations inside sections $\mathrm{A}$ to $\mathrm{C}$ and within an external ooze droplet isolated from 27 sets of samples from field-grown Kit Jonathan apple trees in 2014 inoculated with E. amylovora Ea110. B, Average size of E. amylovora populations inside sections A to $\mathrm{C}$ and an external ooze droplet isolated from apple Buckeye Gala trees inoculated with strain Ea110 from two growth chamber experiments yielding 27 sets of samples. from ooze droplets by insects such as flies. E. amylovora is thought to have originated in North America, occurring as a pathogen on native Rosaceae species. When considering the dissemination of E. amylovora from cankers among native Rosaceae trees, these trees were likely scattered randomly in the landscape, with potentially large distances between them. Flies contacting ooze on a canker would likely only pick up fractions of a microliter of ooze, necessitating dense bacterial populations to ensure successful carriage and cell delivery between canker and flower. There would also be a time component between acquisition and delivery; it is possible that the EPS matrix of ooze would enhance survival during this dissemination phase. For shoot infection in orchards, freshly
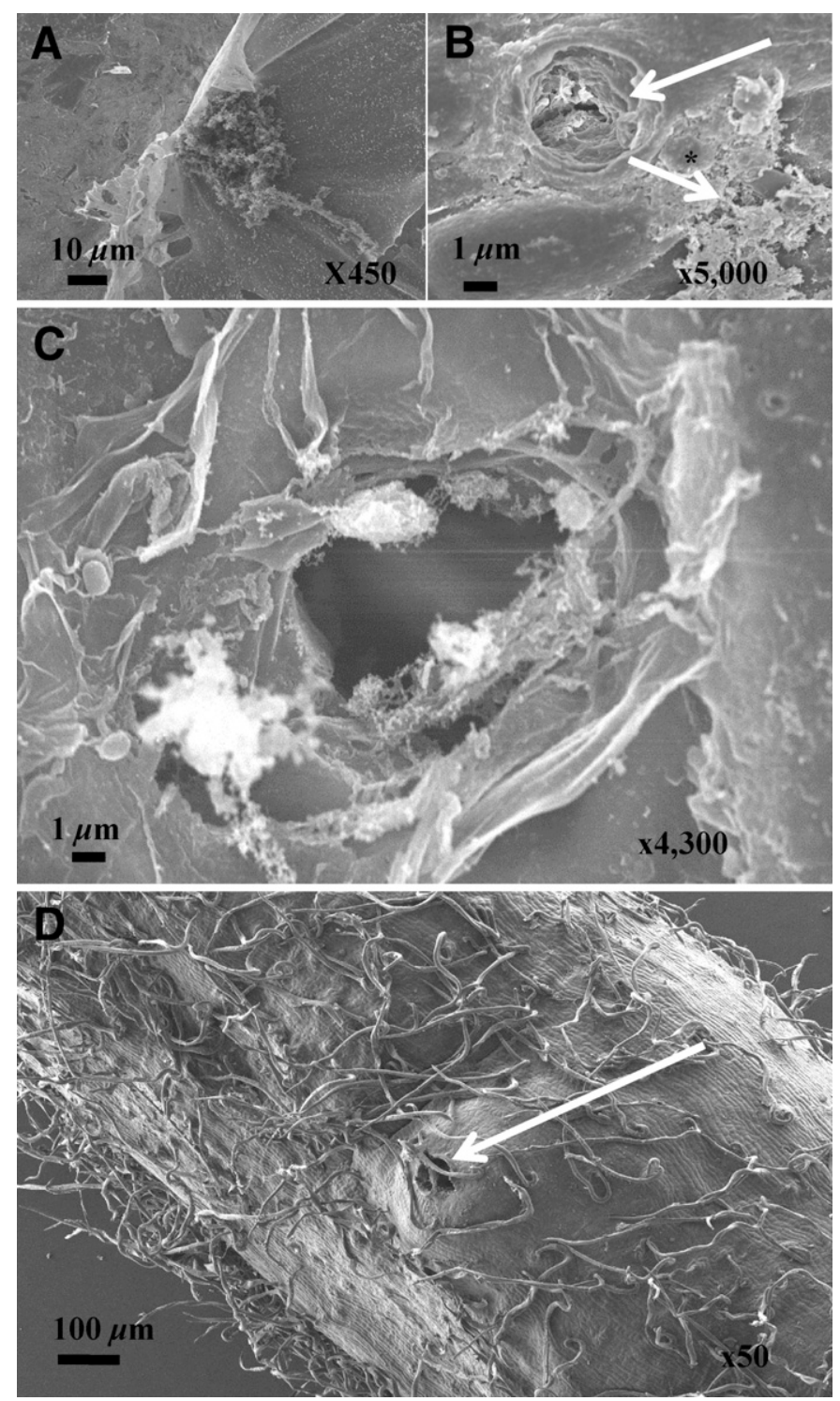

Fig. 6. Scanning electron micrographs of ooze droplets from various Erwinia amylovora-inoculated apple tissue. A, Scanning electron microscopy (SEM) micrograph of a collapsed ooze droplet (zoomed to $\times 450$ ) that formed on an infected immature apple fruit. The ooze droplet was not removed before SEM critical point drying of the fruit. B, Close-up of the origin of an ooze droplet on an infected immature apple fruit. The arrow with an asterisk points to dried ooze next to the opening; the other arrow points to the origin of the ooze droplet. C, Close-up of an exit point by an E. amylovora ooze droplet on an inoculated stem. The ooze droplet was allowed to dry before the SEM critical point fixation processing, allowing for the sheet-like structures to remain intact through the critical point drying process. D, An erumpent mound observed underneath a large ooze droplet on a leaf petiole from an inoculated stem. The ooze droplet was removed prior to critical point drying for SEM fixation. The arrow points to the exit point of the ooze droplet. 
injured tissue at shoot tips is not always available and the size of available wounds would likely be smaller than those generated in inoculation studies; thus, larger cell populations would probably be required to initiate shoot infections than those reported previously in wound inoculation studies (Crosse et al. 1972; Ruz et al. 2008). This again would signify a requirement for very large E. amylovora populations in ooze. In addition, during the long-term period of cell survival in dried ooze, a large percentage of the population may die, thus necessitating a high initial population to allow for the survival of the pathogen. Finally, although the E. amylovora populations in ooze droplets are very large, our analyses indicated that these populations represented, at most, $36 \%$ of the total E. amylovora population within the infected shoot. Thus, ooze represents an allocation of infecting cells to dissemination, meaning that a larger proportion of cells are available for continued systemic infection of the host.

When ooze droplets were examined in the field, they ranged in color from white to dark red; the color did not change if the ooze droplets were allowed to dry. Ooze droplets of various colors from white to deep red and including brown, orange, and yellow have been observed emerging from E. amylovora-infected apple hosts by others (Hildebrand 1939; van der Zwet and Keil 1979). In addition, ooze droplets of various colors have been observed on additional hosts with fire blight symptoms, including cotoneaster, hawthorn, loquat, and Stranvaesia spp. (Eden-Green and Billing 1972; Martin 1922; Meijneke 1967; van der Zwet and Keil 1979). In hosts other than apple, ooze droplets observed at the initiation of infections were lighter in color than those observed later (Eden-Green and Billing 1972; Meijneke 1967; van der Zwet and Keil 1979). However, on apple, E. amylovora ooze droplets appear colored at random, according to others' observations and our own (Hildebrand 1939; van der Zwet and Keil 1979). We observed that E. amylovora populations were consistently larger in darker-colored ooze droplets than in white or yellow ooze droplets but a mechanistic relationship between color and population size has not been determined.

When ooze is released from cankers on apple, it is typically colored orange to dark red. Our field observations confirm those made by others in observing a high frequency of visits by flies to oozing cankers, with the flies walking through and appearing to consume the ooze droplets (Ark and Thomas 1936; Hildebrand 1939; Hildebrand et al. 2000; van der Zwet and Keil 1979). Flies and other insects may be more highly attracted to darker-colored ooze droplets; however, whether the color of ooze is directly influencing insect attraction remains unknown. An alternate possibility is that the attraction of insects to ooze droplets may be more stimulated by the sugar content of these droplets. In addition, the source of color in ooze droplets is unknown. We performed spectrometry analyses of dark-colored versus white ooze droplets and detected increases in host-derived flavanone compounds in the dark-colored ooze (S. M. Slack and G. W. Sundin, unpublished information). Other than being synthesized as a potential defense response to E. amylovora, the role of these compounds in the host response is unknown or circumstantial at best (Flachowsky et al. 2012).

The E. amylovora cells present in ooze droplets exhibited levels of expression of virulence genes that were reduced compared with cells that were recovered from either stem sections near the point of inoculation or stem sections immediately adjacent to the ooze droplet. However, it should be noted that the expression level of $h r p L$ in cells from ooze droplets, for example, was similar to that observed from cells grown in Hrp MM, which is used for the induction of expression of T3SS genes in vitro. It is important that the T3SS genes were actively expressed in E. amylovora cells recovered from ooze droplets because it suggests that the cells were not in biofilm development mode; genes required for biofilm formation and type III secretion are typically inversely regulated (Ahmad et al. 2011; Kuchma et al. 2005; Romling et al. 2013). A critical signaling molecule involved in this inverse regulation phenotype is the second messenger compound cyclic dimeric guanosine monophosphate (cyclic di-GMP) (Romling et al. 2013). Cyclic di-GMP- mediated regulation of virulence is important in E. amylovora-host interactions, and we have shown that E. amylovora mutants containing reduced intracellular levels of cyclic di-GMP (consistent with T3SS gene expression and lack of biofilm formation) are more invasive in shoot infection assays (Edmunds et al. 2013). Thus, even though ooze droplets consist of E. amylovora cells within a matrix of amylovoran EPS (Eden-Green and Knee 1974), ooze does not represent E. amylovora cells in a biofilm. Biofilm development by E. amylovora is initiated by the attachment of cells to a surface; amylovoran is required for biofilm formation and the additional EPS levan contributes to fully mature biofilms (Koczan et al. 2009, 2011). In contrast, E. amylovora cells in ooze droplets most likely exist as a mass of cells and amylovoran that are not actively attached to

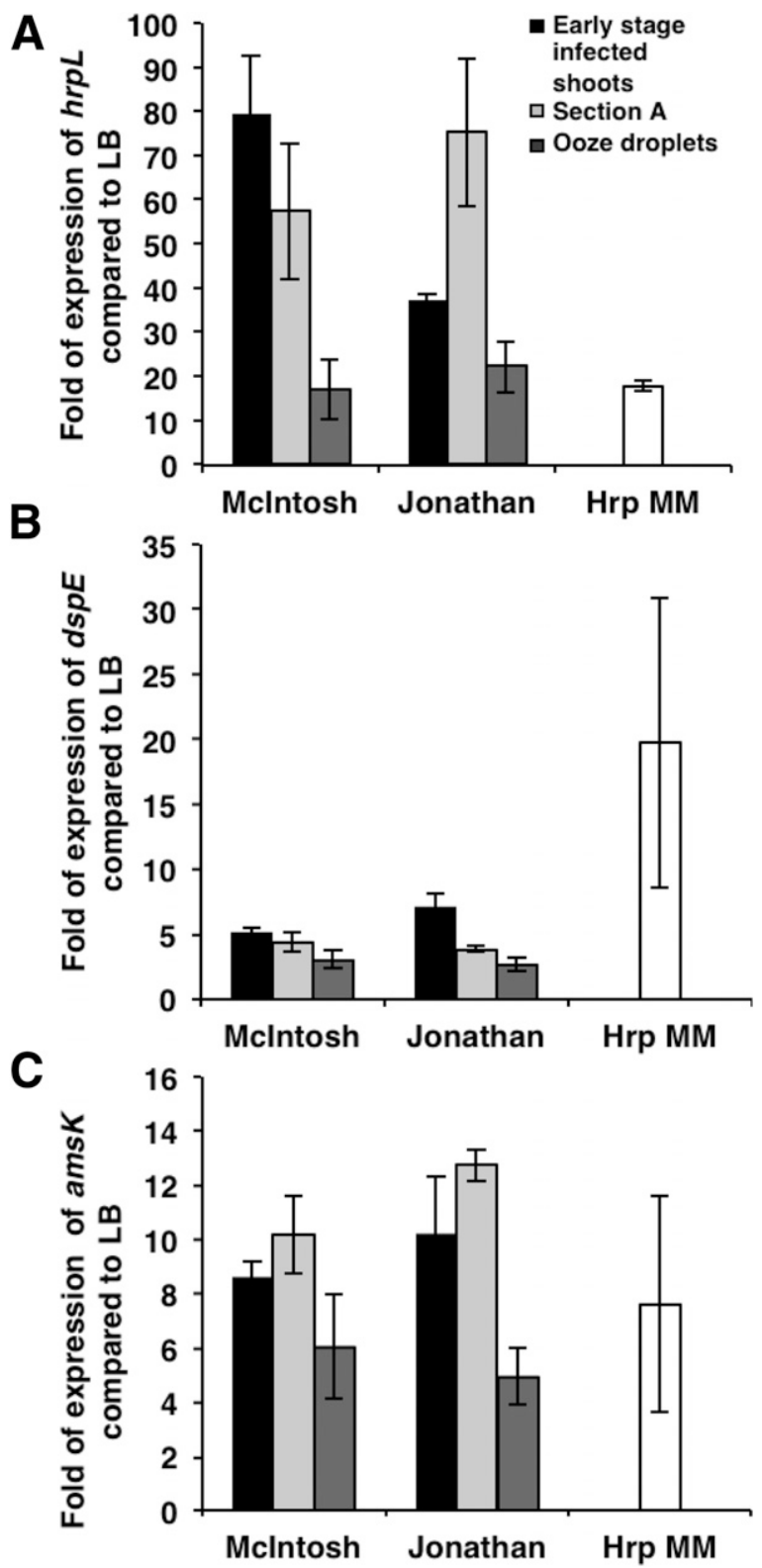

Fig. 7. Relative expression of various pathogenicity genes in different infected plant tissues and ooze droplets from Linda McIntosh and Kit Jonathan fieldinoculated trees and Hrp-inducing minimal medium (Hrp MM) in comparison with expression levels in Luria-Bertani (LB) medium. Samples consisted of five ooze droplets, three samples of section A pieces $(1 \mathrm{~cm}$ section above ooze droplet), three samples of early-stage infected shoots from each cultivar, and three samples each of Hrp MM and LB medium. Three technical replicates of each sample were included. Expression levels of target genes were quantified by a comparative cycle threshold $(\triangle \Delta \mathrm{CT})$ method, normalized by an endogenous control recA. Relative expression of $\mathbf{A}, h r p L ; \mathbf{B}, d s p E$; and $\mathbf{C}$, amsK. 
surfaces and are freely available for dissemination through either insect activity or the effects of wind and rain.

The other important consequence of our detection of active T3SS gene expression by E. amylovora in ooze droplets and in the stem section adjacent to the ooze droplet is that it suggests that the E. amylovora cells migrating through stems that end up emerging in ooze are actively infecting plant cells and likely migrating through the intercellular spaces of the cortical parenchyma. Evidence from a large number of early studies and field observations of fire blight infection indicated that systemic migration of E. amylovora in trees occurs via intercellular spaces of the cortical parenchyma (Billing 2011; Vanneste and Eden-Green 2000). This type of migration is suggestive of E. amylovora-plant cell interactions and T3SS-mediated pathogenesis, requiring $h r p$ gene expression.

Additional studies have shown that E. amylovora also colonizes xylem vessels, and systemic spread within trees through xylem vessels has been proposed as the main mechanism for migration and causing of the wilting symptom of fire blight (Aldwinckle and Preczewski 1976; Crosse et al. 1972; Suhayda and Goodman 1981). It is clear that E. amylovora does colonize xylem vessels; in fact, we have shown that biofilm formation is an important mechanism of xylem colonization and population increases in apple leaves at shoot tips during the early phase of shoot infection (Koczan et al. 2009). Furthermore, it has been shown that E. amylovora cells can "break out" of xylem vessels by direct disruption of the xylem vessel and egress of cells into the intercellular spaces of surrounding parenchyma cells (Bogs et al. 1998). Thus, xylem colonization and biofilm development may be important initially in fire blight pathogenesis as a mechanism increasing the growth of pathogen populations to very high levels in planta. The subsequent systemic migration of E. amylovora downward through trees is more likely accomplished via the cortical parenchyma. This migration is effected by T3SS-mediated killing of plant cells supplying energy to the bacterial pathogen cells and also places the bacterial cells nearer to the outer surface of the plant stems, enhancing the exodus of a portion of the bacterial population as ooze.

Another question we addressed was: How do E. amylovora cells escape the host in ooze droplets? It has been reported that ooze droplets emerging from pear stems were exiting through stomata or lenticels (Zamski et al.2007), although microscopic analyses were not conducted in this study to ensure that natural openings represented the only means of exit for ooze droplets. Based on our SEM imaging studies of stem and fruit tissue, ooze droplets appear to have been formed on the surface after a rupturing of the parenchyma and epidermis layers of the tissue. From 1988 to 1991, Schouten published a series of theoretical articles assessing the role in fire blight pathogenesis of water potential and of increased pressure within the intercellular spaces of the plant host caused by E. amylovora cells and EPS (Schouten 1989a,b, 1991). Eden-Green (1972) had also hypothesized that E. amylovora cells growing within host intercellular spaces create a mechanical pressure. Expanding masses of bacteria, accompanied by EPS, present within a restricted space may ultimately result in pressure on surrounding host cells of a suitable degree that it could cause tearing of host tissue, especially soft tissue (Schouten 1991). Our visualization using SEM of erumpent mounds underneath wounds from which ooze droplets exuded (Fig. 6D) is further evidence supporting the "pressure hypothesis" of Schouten. Schouten further described blisters observed on fire blight-diseased thin shoots of hawthorn or Cotoneaster spp. that were full of masses of bacteria (Schouten 1991); these macroscopic blisters would appear to be functionally similar to the microscopic erumpent mounds we observed in apple tissue. Ooze droplets are most commonly observed exuding from infected stem or flower peduncle tissue in advance of disease symptoms. This is in agreement with the pressure hypothesis in that internal pressure in host tissues increases when E. amylovora cell masses and EPS are growing within intercellular spaces of intact cells. Once extensive cell death occurs, the leakage of host cells and disruption of cell integrity would inhibit pressure development (Schouten 1991). Ooze droplets are not as readily observed on symptomatic tissue, possibly because of decreases in intercellular pressure buildup and also probably because extensive growth and cell division of E. amylovora is occurring at the boundaries of and ahead of the symptomaticasymptomatic tissue boundary.

In summary, we have further characterized E. amylovora ooze droplets from a microbiological and pathogenesis perspective. The critical importance of ooze in the epidemiology of fire blight is likely due to the extremely large and concentrated E. amylovora cell populations in ooze. Widespread dissemination of E. amylovora from ooze droplets through orchards during damaging storms with high winds and hail and the extent of subsequent shoot infections observed is easily explained when considering the population numbers of cells in ooze and the much smaller numbers needed to initiate shoot infections. Dissemination of E. amylovora cells from ooze droplets by insects, although of less importance in commercial apple and pear orchards, likely played a significant role in the life cycle E. amylovora among native Rosaceae trees during the evolution of this pathogen. The simultaneous deployment of cells to both systemic spread through individual host trees and spread between trees via ooze droplet emergence represents two highly effective strategies for the pathogenesis of E. amylovora that continue to cause significant problems for the successful management of fire blight disease.

\section{ACKNOWLDEGMENTS}

We thank Eve Billing for helpful discussions prior to the initiation of this work and Simon Eden-Green for graciously sending us a copy of his Ph.D. dissertation. This research was funded by Project GREEEN (a Michigan plant agriculture initiative at MSU), MSU AgBioResearch, the Michigan Apple Committee, and the Michigan Tree Fruit Commission. Suzanne M. Slack is an MSU Plant Science Initiative graduate fellow.

\section{LITERATURE CITED}

Ahmad, I., Lamprokostopolou, A., Le Guyon, S., Streck, E., Barthel, M., Peters, V., Hardt, W.-D., and Romling, U. 2011. Complex c-di-GMP signaling networks mediate transition between virulence properties and biofilm formation in Salmonella enterica serovar Typhimurium. PLoS One 6:e28351.

Aldwinckle, H. S., and Preczewski, J. L. 1976. Reaction of terminal shoots of apple cultivars to invasion by Erwinia amylovora. Phytopathology 66: 1439-1444.

Ark, P. A., and Thomas, H. E. 1936. Persistence of Erwinia amylovora in certain insects. Phytopathology 26:375-381.

Bennett, A. R., and Billing, E. 1979. Origin of the polysaccharide component of ooze from plants infected with Erwinia amylovora. J. Gen. Microbiol. 116:341-349.

Bernhard, F., Coplin, D. L., and Geider, K. 1993. A gene cluster for amylovoran synthesis in Erwinia amylovora: Characterization and relationship to cps genes in Erwinia stewartii. Mol. Gen. Genet. 239:158-168.

Billing, E. 1981. Weather analysis and fireblight in different climates. Acta Hortic. 177:45-48.

Billing, E. 2011. Fire blight. Why do views on host invasion by Erwinia amylovora differ? Plant Pathol. 60:178-189.

Bogs, J., Bruchmuller, I., Erbar, C., and Geider, K. 1998. Colonization of host plants by the fire blight pathogen Erwinia amylovora marked with genes for bioluminescence and fluorescence. Phytopathology 88:416-421.

Crosse, J. E., Goodman, R. N., and Shaffer, W. H. 1972. Leaf damage as predisposing factor in the infection of apple shoots by Erwinia amylovora. Phytopathology 62:176-182.

Eden-Green, S. J. 1972. Studies in fire blight disease of apple, pear, and hawthorn (Erwinia amylovora (Burrill) Winslow et al.). Ph.D. thesis. University of London, London, U.K.

Eden-Green, S. J., and Billing, E. 1972. Fireblight: Occurrence of bacterial stands on various hosts under glasshouse conditions. Plant Pathol. 21:121-123.

Eden-Green, S. J., and Knee, M. 1974. Bacterial exopolysaccharide in fireblight exudate. J. Gen. Microbiol. 81:509-512.

Edmunds, A. C., Castiblanco, L. C., Sundin, G. W., and Waters, C. M. 2013. Cyclic di-GMP modulates the disease progression of Erwinia amylovora. J. Bacteriol. 195:2155-2165. 
Flachowsky, H., Halbwirth, H., Treutter, D., Richter, K., Hanke, M.-V., Szankowski, I., Gosch, C., Stich, K., and Fischer, T. C. 2012. Silencing of flavanone-3-hydroxylase in apple (Malus $\times$ domestica Borkh.) leads to accumulation of flavanones, but not to reduced fire blight susceptibility. Plant Physiol. Biochem. 51:18-25.

Geider, K., Auling, G., Du, Z., Jakovljevic, V., Jock, S., and Völksch, B. 2006. Erwinia tasmaniensis sp. nov., a non-phytopathogenic bacterium from apple and pear trees. Int. J. Syst. Evol. Microbiol. 56:2937-2943.

Gowda, S. S., and Goodman, R. N. 1970. Movement and persistence of Erwinia amylovora in shoot, stem, and root of apple. Plant Dis. Rep. 54:576-580.

Guttman, D. S., Vinatzer, B. A., Sarkar, S. F., Kettler, G., and Greenberg, J. T. 2002. A functional screen for the type III (Hrp) secretome of the plant pathogen Pseudomonas syringae. Science 295:1722-1726.

Hildebrand, E. M. 1939. Studies on fire-blight ooze. Phytopathology 29: 142-156.

Hildebrand, M., Dickler, E., and Geider, K. 2000. Occurrence of Erwinia amylovora on insects in a fire blight orchard. J. Phytopathol. 148:251-256.

Johnson, K. B., Sawyer, T. L., and Temple, T. N. 2006. Rates of epiphytic growth of Erwinia amylovora on flowers common in the landscape. Plant Dis. 90:1331-1336.

Koczan, J. M., Lenneman, B. R., McGrath, M. J., and Sundin, G. W. 2011. Cell surface attachment structures contribute to biofilm formation and xylem colonization of Erwinia amylovora. Appl. Environ. Biol. 77:7031-7039.

Koczan, J. M., McGrath, M. J., Zhao, Y., and Sundin, G. W. 2009. Contribution of Erwinia amylovora exopolysaccharides amylovoran and levan to biofilm formation: Implications in pathogenicity. Phytopathology 99:1237-1244.

Kuchma, S. L., Connolly, J. P., and O'Toole, G. A. 2005. A three component regulatory system regulated biofilm maturation and type III secretion in Pseudomonas aeruginosa. J. Bacteriol. 187:1441-1454.

Martin, J. P. 1922. Variation in color of pear blight exudate. Phytopathology $12: 399-400$.

McGhee, G. C., and Sundin, G. W. 2011. Evaluation of kasugamycin for fire blight management, effect on nontarget bacteria, and assessment of kasugamycin resistance potential in Erwinia amylovora. Phytopathology 101:192-204.

McNally, R. R., Toth, I. K., Cock, P. J., Pritchard, L., Hedley, P. E., Morris, J. A., Zhao, Y., and Sundin, G. W. 2012. Genetic characterization of the HrpL regulon of the fire blight pathogen Erwinia amylovora reveals novel virulence factors. Mol. Plant Pathol. 13:160-173.

Meijneke, C. A. R. 1967. Fire blight: An isolated outbreak in the Netherlands. Eur. Med. Plant Prot. Org. Ser. A 45E:17-19.

Miller, T. D., and Schroth, M. N. 1972. Monitoring the epiphytic population of Erwinia amylovora on pear with a selective medium. Phytopathology 62: 1175-1182.

Momol, M. T., Norelli, J. L., Piccioni, D. E., Momol, E. A., Gustafson, H. L., Cummins, J. N., and Aldwinckle, H. S. 1998. Internal movement of Erwinia amylovora through symptomless apple scion tissues into the rootstock. Plant Dis. 82:646-650.

Norelli, J. L., Jones, A. L., and Aldwinckle, H. S. 2003. Fire blight management in the twenty-first century: Using new technologies that enhance host resistance in apple. Plant Dis. 87:756-765.

Oh, C.-S., and Beer, S. V. 2005. Molecular genetics of Erwinia amylovora involved in the development of fire blight. FEMS Microbiol. Lett. 253:185-192.
Pusey, P. L., and Curry, E. A. 2004. Temperature and pomaceous flower age related to colonization by Erwinia amylovora and antagonists. Phytopathology 94:901-911.

Romling, U., Galperin, M. Y., and Gomelsky, M. 2013. Cyclic di-GMP: The first 25 years of a universal bacterial second messenger. Microbiol. Mol. Biol. Rev. 77:1-52.

Ruz, E. L., Moragrega Garcia, C., and Montesinos, E. 2008. Evaluation of four whole-plant inoculation methods to analyze the pathogenicity of Erwinia amylovora under quarantine conditions. Int. Microbiol. 11: 111-119.

Schouten, H. J. 1989a. Notes on the role of water potential in the pathogenesis of fire blight, caused by Erwinia amylovora. Neth. J. Plant Pathol. 94: 213-220.

Schouten, H. J. 1989b. A possible role in pathogenesis for the swelling of extracellular slime of Erwinia amylovora at increasing water potential. Neth. J. Plant Pathol. 95:169-174.

Schouten, H. J. 1991. Simulation of potential caused by multiplication and swelling of Erwinia amylovora in intercellular space of host tissue. Neth. J. Plant Pathol. 97:139-149.

Schroth, M. N., Thompson, S. V., Hildebrand, D. C., and Moller, W. J. 1974. Epidemiology and control of fire blight. Annu. Rev. Phytopathol. 12: 389-412.

Seemüller, E. A., and Beer, S. V. 1976. Absence of cell wall polysaccharide degradation of Erwinia amylovora. Phytopathology 66:433-436.

Sijam, K., Karr, A. L., and Goodman, R. N. 1983. Comparison of the extracellular polysaccharides produced by Erwinia amylovora in apple tissue and cultured medium. Physiol. Plant Pathol. 22:221-231, IN11-IN12.

Suhayda, C. G., and Goodman, R. N. 1981. Early proliferation and migration and subsequent xylem occlusion by Erwinia amylovora and the fate of its extracellular polysaccharide (EPS) in apple shoots. Phytopathology 71: 697-707.

Thomson, S. V. 1986. The role of the stigma in fire blight infections. Phytopathology 76:476-482.

Thomson, S. V. 2000. Epidemiology of fire blight. Pages 9-36 in: Fire Blight: The Disease and Its Causative Agent, Erwinia amylovora. J. L. Vanneste, ed. CABI Publishing, Oxon, UK.

van der Zwet, T., and Keil, H. L. 1979. Fire Blight: A Bacterial Disease of Rosaceous Plants. United States Department of Agriculture, Washington, DC.

van der Zwet, T., Orolaza-Halbrendt, N., and Zeller, W. 2012. Fire Blight History, Biology, and Management. American Phytopathological Society, St. Paul, MN.

Vanneste, J. L., and Eden-Green, S. 2000. Migration of Erwinia amylovora in host plant tissues. Pages 73-83 in: Fire Blight: The Disease and Its Causative Agent, Erwinia amylovora. J. L. Vanneste, ed. CABI Publishing, Oxon, UK.

Zamski, E., Shtienberg, D., and Blachinsky, D. 2007. The role of ooze exudation in the migration of Erwinia amylovora cells in pear trees infected by fire blight. Isr. J. Plant Sci. 54:301-307.

Zhao, Y., Blumer, S. E., and Sundin, G. W. 2005. Identification of Erwinia amylovora genes induced during infection of immature pear tissue. J. Bacteriol. 187:8088-8103. 